medical benefits and pensions, but the expenses connected with leasing were high (and accounted for nearly one half of the drivers "expenses" by 2006), and the hours long. Hodges notes that one analyst estimated that when adjusted for inflation the income of drivers was less in 2003 than it had been in 1929. Moreover, new times meant new problems. In recent years a fleet of gypsy cabs and limo services offered competition that was hard to regulate, even with the best of intentions at city hall. If cabs refused to pick up black passengers then the gypsy drivers were eager for the fare. The conditions revealed in television and film of grinding poverty and alienation were accurate. No wonder as European immigrants found better jobs, they declined in numbers as taxi men. Their places were taken by new immigrants, Africans and Asians, especially Indians and Pakistanis, thus opening a new era in the taxi industry.

David M. Reimers

New York University

\title{
Fabio Riojas, From Black Power to Black Studies: How a Radical Social Movement Became an Academic Discipline (Baltimore: Johns Hopkins University Press, 2007).
}

The Black Power Movement indelibly transformed race relations in America. Stokely Carmichael's 16 June 1966 declaration of "Black Power!" during a civil rights march in Greenwood, Mississippi catalyzed the black freedom struggle. Immediately following the march, the Black Power slogan elicited controversy among whites and inspired hope in black militants. Carmichael defined the term as a call for black self-determination, cultural pride, and economic autonomy. At the national level, between 1966 and 1975, Black Power infused virtually every aspect of American society. Black Power activists organized for community control of schools, electoral power in major cities, prisoner, labour, and welfare rights, and advocated a cultural politics that became known as the Black Arts Movement.

Black students, both at universities and in high schools, staged raucous protests centered on demands to promote black history in the educational curriculum. Fabio Riojas' From Black Power to Black. Studies: How a Radical Movement Became an Academic Discipline is a sociological examination of the Black Studies Movement. Riojas traces the movement's origins to the radicalization of the civil rights movement in the early 1960s, when black nationalists-building on the pioneering scholarship of W.E.B. Du Bois and Carter Woodson, pushed for autonomous black institutions. Civil right reforms, urban rebellions, and demographic changes provided Black Power militants with the opening they were looking for. San Francisco State College became the headquarters for a national movement for Black Studies led by former Student Non-Violent Coordinating Committee (SNCC) member (and Black Panther) Jimmy Garrett. At San Francisco State, 
Black Studies became embroiled in a national controversy that pitted radicalized students, Black Panthers, and sympathetic professors against university administrators, local authorities, and Governor Ronald Reagan. Riojas does a good job of exploring how Black Studies evolved at several institutions, including the University of Chicago, Harvard, and the University of Illinois. While some students proposed a more community oriented concept that would encourage participation of blacks outside the ivory tower of academe, in the end what would prove most enduring was 'academic black studies' that paralleled existing disciplinary structures and frameworks. The discussion of the Ford Foundation's role in shaping Black Studies through grant support is subtle and balanced, with Riojas arguing that the foundation had "a modest effect on the black studies field" (163). From Black Power to Black Studies concludes by analyzing the way in which Black Studies has evolved into a legitimate academic discipline within the America academy, one that tends to exist in elite research universities and originated in student protests. By the twenty-first century Black Studies had grown into a respected, if still controversial and somewhat stigmatized, academic discipline with a cadre of highly respected professional intellectuals with a distinctively interdisciplinary corpus of scholarship. Riojas concludes by arguing that these developments are a direct outgrowth of Black Studies' rejection of cultural nationalism for an interdisciplinary model that allows for cosmopolitan intellectual perspectives that range from postmodernism to Afrocentrism. As Riojas writes, "Black studies achieved a degree of stability by abandoning cultural nationalism and community education" (215). Subsequently the programs focused on scholarly research and educating elites, a trend that has ensured the movement's institutionalization at the expense of what many of its architects imagined more than forty years ago. However, Riojas still sees Black Studies as informing an oppositional space within higher education, maintaining an outsider-insider status that has resisted, up to a point, mainstream co-optation.

From Black Power to Black Studies is a valuable sociological study of the way in which militant student protest led to the institutionalization of African American Studies in higher education. Moreover, it provides insightful analyses of the pitfalls, both institutionally and politically, that have conspired to hamper Black Studies' growth and legitimacy as an academic discipline. In doing so it adds to a growing literature that will lead to a comprehensive history of the origins, evolution, and contemporary relevance of Black Studies.

Although Riojas' study provides valuable insights, it is less successful in providing a historical context for the Black Studies Movement. Black Power radicalism, and not civil rights, provided the grassroots mobilization and political and cultural thrust for the movement. Black Power activists viewed Black Studies as one of many important struggles for self-determination in the United States and abroad. While Riojas mentions this, the study's sociological emphasis disallows from the thick historical description that the Black Studies movement deserves. 
Riojas' study, which tackles questions concerning how organizations and bureaucracies respond to pressure from insurgent movements, will be of less interest to historians on this score. Furthermore, one wishes that Riojas' study would have displayed a historiographical engagement with some of the important monographs and essays comprising the new Black Power scholarship. Nonetheless, Riojas has provided a thoughtful and substantive contribution to the emerging new literature on the origins of Black Studies.

Peniel E. Joseph

Brandeis University

\section{Richard Hudelson and Carl Ross, By the Ore Docks: $A$ Working People's History of Duluth (Minneapolis: Unive rsity of Minnesota Press, 2006).}

\section{Joe William Trotter Jr., Black Milwaukee: The Making of an Industrial Prole tariat 1915-1945, Second Edition, (Urbana, IL: University of Chicago Press, 2007).}

In the fall of 1994, International Labor and Working Class History printed a series of essays and comments under the title "ILWCH Roundtable: What Next for Labor and Working Class History?" The scholars contributing to the roundtable disagreed as to whether there was in fact a crisis in the discipline or whether labour history was, in the words of one essay title, "out of vogue". Despite the cautious optimism evinced by a majority of the contributors, anxieties over the demise of the new labour history-especially in its Anglo-American form-have only increased since the mid 1990's thanks to the ascendance of the cultural turn and the West's move towards a post industrial economy. Such developments have diluted the explanatory force of class analysis which is fundamental to the new labour history's objective of forging a 'usable' past. In light of these occurrences the recent publication of Richard Hudelson and Carl Ross' By the Ore Docks: A Working People's History of Duluth and the second edition of Joe W. Trotter's new labour classic, Black Milwankee: The Making of an Industrial Proletariat 1915-45 seems defiantly nostalgic.

Indeed, By the Ore Docks is chiefly concerned with revealing the indebtedness which the currently revitalized labour movement of Duluth owes to its past (274). The book is a collaborative work which draws on the talent of Richard Hudelson, a philosopher of Marxism at the University of Wisconsin and Carl Ross a local labour activist who served as director of the twentieth century Radicalism in Minnesota Project of the Minnesota Historical Society. Unfortunately, Ross passed away in the spring of 2005 and was unable to comment on late revisions of the book. Impetus for this project was derived from Hudelson's curiosity about the role of communists in Duluth — a community steeped in social democratic ten- 